\title{
BCG Antibody
}

National Cancer Institute

\section{Source}

National Cancer Institute. BCG Antibody. NCI Thesaurus. Code C112055.

Any immunog lobulin that recognizes Bacillus Calmette-Guerin antigen. 